\title{
LABOR MOBILITY AND LABOR MARKET FORMATION: CURRENT TRENDS
}

\section{Petrovskaya I. O.}

\section{INTRODUCTION}

The functioning of the national and regional labor markets is impossible without ensuring labor mobility of the population, which is a condition for balancing the supply and demand of labor. Changes in labour market conditions cause the movement of labour resources. Labour mobility is one of the main factors that ensures labour market flexibility. Therefore, the analysis of labor mobility makes it possible not only to get an idea of how the labor market functions, but also to predict the development of the situation in the field of employment.

\section{Features of labor mobility of youth in the conditions of reformation economy}

The study of youth labor mobility involves three parts. The first is the assessment of economic labor mobility; the second will be devoted to the analysis of territorial labor mobility, the third - the analysis of sectoral labor mobility.

The analysis of economic labor mobility of young people based on the classification of labor resources, which is based on the methodology of the International labor organization. The ILO recommended a classification system whereby the population divided into economically active population (EAP) and economically inactive population (ENP). This approach makes it possible to assess the labor movements of young people who are in the economically active age (from 15 to 70 years), that is, to determine the movement between the employed, unemployed, economically inactive part of the population. Any movement of the individual, which accompanied by a change in his economic status, leads to a change in the economic structure of the population.

The main movements of labor resources, as already mentioned, are limited by the flows between employment, unemployment and the economically inactive population. 
The economically active group (employed and unemployed) includes individuals who focus on income, and in the case of employment - wages. It is the supply and use of labor that characterizes economic activity in employment.

The reasons for economic inactivity in the labor market are primarily due to the availability of income in the form of transfer payments (scholarships, pensions) and the assistance of relatives. The economically inactive part of the population includes: scientists, students, trainees, fulltime students (including full-time graduate and doctoral studies); persons receiving old-age pensions and on preferential terms, as well as receiving disability pensions; persons who do not have the need or desire to work, and those who are looking for work but are not ready to start it in the near future. The economically inactive part of the population includes those who are engaged in housekeeping, caring for children, sick relatives, etc. In addition, one of the reasons for the economic inactivity of the population is the inability to find work, that is, this category includes persons who have stopped searching, exhausted all possibilities of obtaining it, which leads to the refusal of employment and transition from the group of economically active population (unemployed) to economically inactive.

Necessity to determine the intensity of the flow between EAP and ENP is justified by the fact that the result of economic labor mobility is an increase or decrease in the supply of young people in the labor market. These data make it possible to characterize the behavior of economically active young people, the probability of maintaining their economic status by this group, which makes it possible to predict the situation in the labor market and use this information in programs to promote youth employment and their professional orientation.

The next form of labor movement is territorial labor mobility, or labor migration.

An important component of the definition of labor mobility is the analysis of migration of economically active youth. Thus, the existing negative trends in the development of socio-economic processes, which have become stable and have been reflected, first of all, in such phenomena as high unemployment; low price of labor, and as a consequence, low income of the bulk of the population; imbalance between demand and supply of labor and limited opportunities for effective employment. The 
strengthening of these problems is taking place against the background of the Operation of the joint forces in the Donetsk and Luhansk regions, political instability in society and many other factors that have led to increased labor migration of the population not only outside the state, but also from one region of Ukraine to another.

The consequences of these processes are not only the increase in the volume of inter-state migration, but also the concentration of young people in large industrial cities (where the level and quality of life is higher, and the unemployment rate is much lower) and deserted small towns and rural settlements; the dependence of the economic system on shadow business and other negative phenomena, which, in turn, caused a sharp aggravation of the crime situation.

During the whole period of Ukraine's stay in the USSR, the labor migration activity of young people was kept at a high level. Therefore, since the beginning of World War II there was a mass evacuation of people, especially from the cities of Ukraine, to the Eastern regions of the USSR. Germans and Tatars were forcibly removed from their settlements. There was also a forced removal of young people from the occupied territories of Ukraine to work in Germany ${ }^{1}$.

In the first post-war years, organized resettlement was widely developed - the recruitment of labor for new buildings in the Eastern regions of the former Union and the development of virgin lands, the construction of the Baikal-Amur mainline, as well as the forced removal (deportation from the territory of Ukraine of certain ethnic groups and politically repressed persons). Over time, organized migration was replaced by spontaneous individual migrations, which also involved many people. This was facilitated by the availability of jobs in the country, so that citizens of the former Union had the confidence to get a job, and therefore the means of subsistence after moving and therefore relatively easy to decide on migration ${ }^{2}$.

The impact of migration on the total population of Ukraine during 1960 - 1980 was insignificant, but on the qualitative composition of the population - clearly negative. During 1959-1989 the population of Ukraine

\footnotetext{
1 Tarnavsky M. P. Migration processes in Ukraine: causes and consequences. Scientific works of Kirovograd national technical University. Series: Economic Sciences. 2012. Issue. 22. Part 1. P. 4.

${ }_{2}^{2}$ First all-Ukrainian population census: historical, methodological, social, economic, ethnic aspects / [N. S. Vlasenko E. M. Libanova, A. G. Osaulenko, etc.]; ed. I. F. Kuras, S. I. Pirozhkova. Kyiv : IVTs state statistics Committee of Ukraine, 2004. P. 340.
} 
grew by less than $1 \%$ in a decade due to mismatches, while as a result of the migration factor the number of men aged 20-29 years decreased for each inter-census period by $5-6 \%$, the number of women of the same age by $2 \%$. However, the number of persons of younger and retirement ages (men 60-69, women 55-69 years) during 1959-1970. Because of migration, it increased by more than $4 \%$, during the next inter-census period - by $2 \%$ and only in the 80 -ies of the last century, this process stopped ${ }^{3}$.

With independence, migration processes in Ukraine and their impact on social and economic development have changed fundamentally. If at the beginning of the nineties a lot of Ukrainians and representatives of national minorities who previously lived in Ukraine (Crimean Tatars, Armenians, Bulgarians, Greeks, Germans and others), began to return (repatriate) to their homeland and the migration balance was positive (in 1992, for example, it was more than 282 thousand people). Then in 1993, the flow of returnees almost stopped and the migration balance becomes negative ${ }^{4}$.

\section{Assessment of labor migration in Ukraine}

The structure of migrant workers by age are shown in Figure $1^{5}$.

At the end of the XX century, migratory processes occurred under the new political, legal and economic conditions associated with the emergence of new independent States, market reforms, Ukraine's entry into the international system of exchange of populations. The first all-Ukrainian census recorded 118.8 thousand people whose place of work is outside Ukraine. This is only a small part of the real population of external labor migrants (1-5 million according to various estimates), although it is three times more than the number recorded by the employment services ${ }^{6}$. Migration processes have an ambiguous impact on the formation of the gender, age, educational and professional structure of the labor market. So migration can actively and quickly influence the demographic situation, reducing or increasing the population, the age and sex structure of the population, changing the conditions of its reproduction. Two laws

\footnotetext{
${ }^{3}$ Demographic crisis in Ukraine: its causes and consequences / [ed. S. I. Pirozhkova]. Kyiv : IVTs. State statistics Committee of Ukraine, 2003. P. 42.

${ }^{4}$ Demographic crisis in Ukraine: its causes and consequences / [ed. S. I. Pirozhkova]. Kyiv : IVTs. State statistics Committee of Ukraine, 2003. P. 42.

${ }^{5}$ Statistical Bulletin "External labour migration (based on the results of a modular sample survey)" / [resp. for issue I. V. Senik]. Kiv : State statistics service of Ukraine, 2017. 36 p.

${ }^{6}$ First all-Ukrainian population census: historical, methodological, social, economic, ethnic aspects / [N. S. Vlasenko E. M. Libanova, A. G. Osaulenko, etc.]; ed. I. F. Kuras, S. I. Pirozhkova. Kyiv : IVTs state statistics Committee of Ukraine, 2004. P. 345.
} 
characterize migration activity of the population. The first forms a positive balance of migration, which indicates the attractiveness of the territory for life, the second - a negative balance, which indicates the presence of both social and economic problems in the territory. Migration processes significantly affect the social division of labor and the level of its payment, the distribution and redistribution of labor, as well as the level of social tension in the regions with a long and intense influx of people. Unfortunately, the quantitative characteristics of migration turnover rarely considered in organic connection with its specific social consequences, which can be both positive and negative.

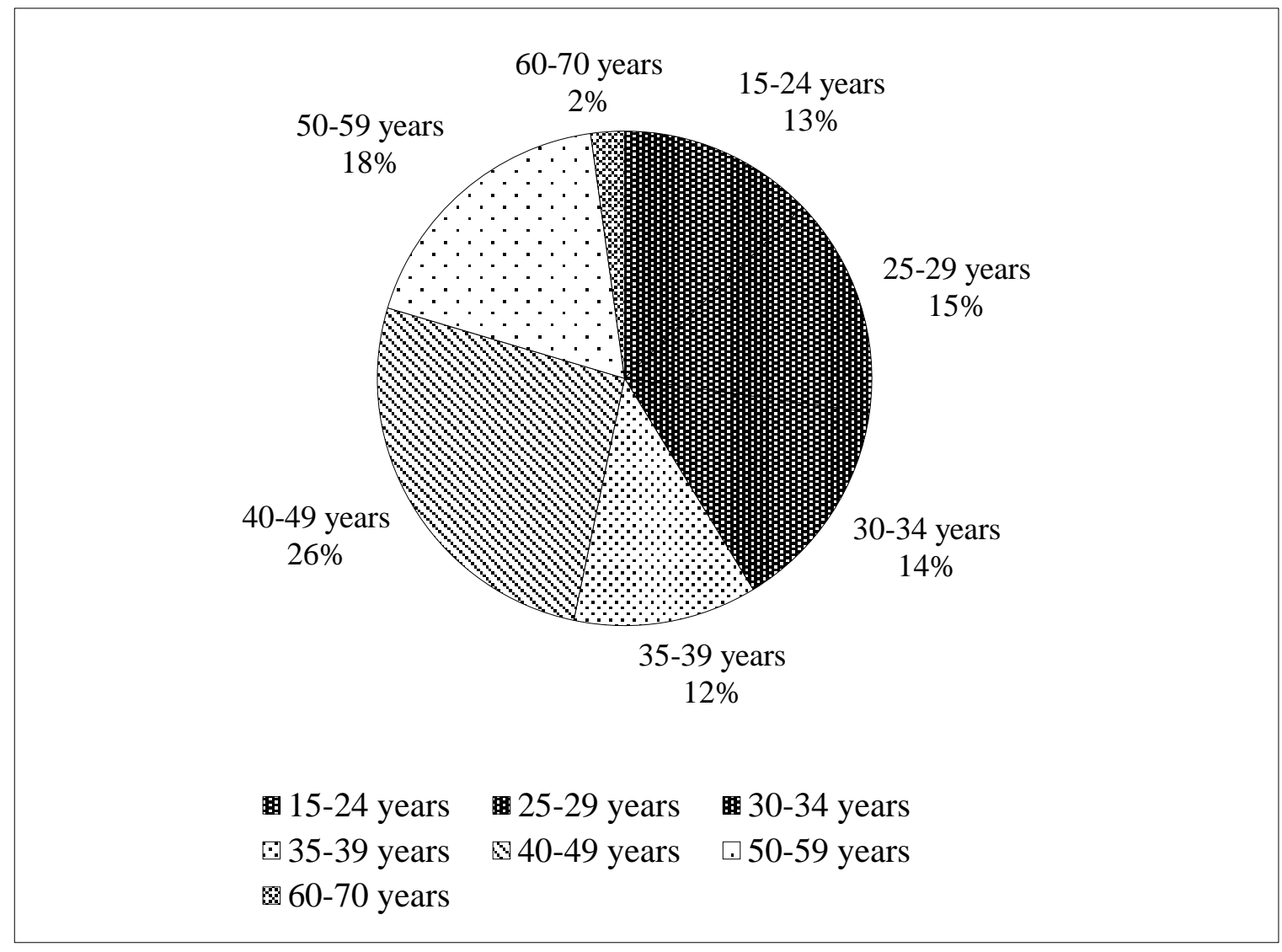

Fig. 1. Structure of labor migrants by age for the period 2015-2017

Analysis of the structure of migration of the population of Ukraine indicates that during the study period, there have been changes in the intensity and direction of migration flows. The dynamics of population losses due to migration tends to decrease, although there are some fluctuations. It should be taken into account that the main share of participants in these processes falls on the working part of the population. 
According to the research of the International organization for migration, every second young Ukrainian aged 20 to 35 years shows a desire to emigrate from Ukraine. The number of visits of Ukrainians to the EU continues to grow-10.5 million in 2014, 12.5 million in 2015. Yes, in 2015, there were 905.2 thousand Ukrainians living in the EU, They accounted for more than $6 \%$ of foreigners from third countries in the EU. Most Ukrainians lived in Italy (238 thousand), Poland (336 thousand), Germany (112 thousand), the Czech Republic (113 thousand) and Spain (84 thousand). Regarding the labor migration of Ukrainians, according to the IOM in 2014-2015. Abroad were about 700 thousand Ukrainian workers. According to the same study, the majority of labor migrants are men, the most numerous of them are 30-44 years old (over 40\%), the majority of migrants come from the Western regions of the country. $41 \%$ of migrant workers have secondary or specialized secondary education, $36 \%$ - higher education. The main destination countries for migrant workers are Poland, the Russian Federation, the Czech Republic and Italy. They account for about $80 \%$ of the total flows of short-term and long-term labor migrants from Ukraine ${ }^{7}$.

The structure of labor migrants by countries of residence and age groups, which provided by the State statistics service of Ukraine, are given in table 1.

The analysis of the dynamics of migration processes by the age composition of labor migrants shows that the main share of participants in these processes falls on the population aged 15-34 years. It's established that the intensity of migration processes of the population of different ages varies. The most mobile group turned out to be mostly young people aged 15 to 34 years (more than $40 \%$ of the total number of migrants), at the time when the school is finished and in the plans of vocational education and employment, as well as employment after graduation.

Traditionally, at the age of 25-29 years ends the period of education and there is an active job search. In addition, the intensity of migration processes influenced by the mentality of society, in particular, the responsibility for the upbringing and education of children, the establishment of family life and so on. In the age groups 30-39 and 40-49, the intensity of migration processes is significantly reduced, which is explained by the presence of a permanent job, the necessary qualifications to perform professional duties, career prospects, obtaining a second higher education, due to industrial necessity, and etc.

\footnotetext{
${ }^{7}$ Stadnyj Y. Number of Ukrainian students abroad. URL: http://www.cedos.org.ru/RU/osvita/56
} 
Table 1

Structure of labor migrants by host country age groups for the period 2015-2017

\begin{tabular}{|c|c|c|c|c|c|c|c|c|}
\hline \multirow[b]{2}{*}{ Country } & \multirow{2}{*}{$\begin{array}{l}\text { Total, } \\
\text { thousand } \\
\text { people }\end{array}$} & \multicolumn{7}{|c|}{ including by age groups, $\%$} \\
\hline & & $\begin{array}{l}15-24 \\
\text { years }\end{array}$ & $\begin{array}{l}25-29 \\
\text { years }\end{array}$ & $\begin{array}{l}30-34 \\
\text { years }\end{array}$ & $\begin{array}{l}35-39 \\
\text { years }\end{array}$ & $\begin{array}{l}40-49 \\
\text { years }\end{array}$ & $\begin{array}{l}50-59 \\
\text { vears }\end{array}$ & $\begin{array}{l}60-70 \\
\text { vears }\end{array}$ \\
\hline 1 & 2 & 3 & 4 & 5 & 6 & 7 & 8 & 9 \\
\hline $\begin{array}{l}\text { Number of } \\
\text { labor } \\
\text { migrants, } \\
\text { total }\end{array}$ & 1303,3 & 12,8 & 14,4 & 14,1 & 12,0 & 26,3 & 18,2 & 2,2 \\
\hline \multicolumn{9}{|c|}{ including by host country } \\
\hline Poland & 506,5 & 17,8 & 18,1 & 10,5 & 14,4 & 24,6 & 13,8 & 0,8 \\
\hline $\begin{array}{l}\text { Russian } \\
\text { Federation }\end{array}$ & 342,4 & 6,9 & 13,6 & 19,8 & 7,9 & 29,6 & 22,2 & - \\
\hline Italy & 146,7 & 2,5 & 8,5 & 5,1 & 5,7 & 30,4 & 39,1 & 8,7 \\
\hline $\begin{array}{l}\text { Czech } \\
\text { Republic }\end{array}$ & 122,5 & 16,1 & 5,9 & 23,6 & 9,7 & 26,0 & 10,0 & 8,7 \\
\hline $\begin{array}{l}\text { United } \\
\text { States of } \\
\text { America }\end{array}$ & 23.5 & - & - & 13,2 & 7,2 & 57,0 & 22,6 & - \\
\hline Belarus & 22,5 & 14,7 & 12,0 & 7,6 & 3,1 & 22,2 & 29,7 & 10,7 \\
\hline Portugal & 20,3 & - & 29,1 & 5,9 & 23,6 & 20,7 & 20,7 & - \\
\hline Hungary & 17,1 & 33,9 & 9,4 & 19.3 & 27,5 & 4,1 & 5,8 & - \\
\hline Israel & 13,9 & - & 36,7 & - & 37,4 & 25,9 & - & - \\
\hline Finland & 13,3 & 39,8 & 27,1 & 21,8 & - & 11,3 & - & - \\
\hline Germany & 10,2 & 12,7 & 24,5 & 29,5 & 13,7 & 7,8 & 11,8 & - \\
\hline $\begin{array}{l}\text { Other } \\
\text { country }\end{array}$ & 64,4 & 21,9 & 11,8 & 17,1 & 27,4 & 16,5 & 5,3 & - \\
\hline
\end{tabular}

The age group of 50-59 years, which is pre-retirement, characterized by low intensity of migration processes. This is due to the low competitiveness in the labor market, the deterioration of physical health, limited professional development etc.

It is proved that the negative consequences of migration processes is, first of all, the outflow of the able-bodied part of the population, in particular, the outflow of young people. These processes contribute to an increase in the proportion of persons of older age groups in the population 
of Ukraine. Moreover, this, in turn, is a serious socio-demographic problem of society.

Thus, it can be considered that an important problem of modern Ukrainian society should be considered the strengthening of migration sentiment, especially for young people. Attempts to solve life problems in the way of employment abroad and contributes to the acquired experience of Ukrainians working outside the state, a powerful migration network, formed over the past decades. A survey commissioned by the International organization for migration in the spring of 2015 showed that $8 \%$ of Ukrainians plan to find work abroad in the near future or have already found it. According to a similar study in 2011, there were $6 \%$.

According to various expert estimates (exact data do not exist), there are from 2.5 million to 8 million migrant workers abroad. On the other hand, the flow of migrants, mostly illegal, to Ukraine is increasing. Under such conditions, there is an urgent need for in-depth study the processes of emigration and immigration taking place on the territory of Ukraine, as well as their impact on the future of Ukraine.

Labor migrations reduce tensions in the labor market. In the absence of employment abroad, the number of unemployed more than doubled their actual number. According to various surveys, the earnings of migrant workers abroad are three to four times higher than the average wage in Ukraine. The money earned during labor migration mainly used for consumption, which helps to improve the quality of life of migrant families, reduce poverty, and stimulates the development of the economy by increasing effective demand. According to the study of financial income associated with migration, and their impact on the development of Ukraine, carried out by IOM in 2014-2015, remittances of migrants to Ukraine account for almost half of the budget of the households, having in its composition of long-term labor migrants, and $60 \%$ of the budget of those members who are in practice short-term labor migration. According to the same study, almost one in five long-term migrant expressed investment intentions, preferring to invest in their local communities in Ukraine and in sectors such as construction, tourism and retail trade ${ }^{9}$.

According to UNESCO, in the period from 2000 to 2012 the number of Ukrainian students abroad has increased more than four times and

\footnotetext{
${ }^{8}$ Stadnyj Y. There are Ukrainian students behind the cordon. URL: http://www.cedos.org.ua/uk/osvita/56

${ }^{9}$ Stadnyj Y. There are Ukrainian students behind the cordon. URL: http://www.cedos.org.ua/uk/osvita/56
} 
reached 37 thousand. According to the annual monitoring of the number of Ukrainian citizens who study at foreign universities in full-time education, carried out by the analytical center CEDOS (covers 34 countries of the world); in the 2013/2014, academic year 47724 citizens of Ukraine studied abroad. Most of them are in Poland (15 thousand), Germany (9 thousand), Russia (6 thousand), Canada (2 thousand), Czech Republic (2 thousand), Italy (1.9 thousand), USA (1.5 thousand), Spain (1.4 thousand), France (1.3 thousand), Great Britain (1 thousand).

It should be noted, that labor mobility flows can be recorded and analyzed both at the level of the economy as a whole - at the macro level, and at the individual enterprise - at the micro level. The results of labor movements at the macro level manifested through changes in the sectoral, territorial and economic structures of employment. At the micro level, labor mobility affects the average number of employees of the enterprise, the number of employees hired and retired, and the turnover of personnel.

There are five forms of labor mobility in the labor market: economic, territorial, sectoral, corporate and professional.

Labor mobility is a dynamic process that is constantly transforming over time. In the process of development of society, labor mobility is changing, which affects its volume, level, composition and structure of participants in this process. Each type of labor mobility develops and changes with the development of society and has its own characteristics.

Features of each type of labor mobility reflected in both quantitative and qualitative indicators. Quantitative and qualitative characteristics of labor mobility are given in table 2 .

To determine the degree of intensity of labor mobility, the following scale for assessing the intensity of labor movements is proposed (Fig. 2).

The minimum level of labor mobility intensity is between 0 and 5 per cent, low between 5 and 30 per cent, medium and high between 30 and 60 per cent and 60 and 90 per cent respectively, and the maximum between 90 per cent and above.

Thus, indicators such as the magnitude and intensity of labour mobility make it possible to conduct a comparative analysis of all forms of labour mobility of young people.

For economic labor mobility, the value of labor movements will be calculated depending on the direction of its flows. 
Table 2

Quantitative and qualitative characteristics of labor mobility

\begin{tabular}{|c|c|}
\hline Quantitative assessment & Qualitative assessment \\
\hline $\begin{array}{l}\text { Scale of labor mobility } \\
\text { The duration of the labor movement } \\
\text { Characteristics of the workplace } \\
\text { before and after labor movement: } \\
\text { ratio of wages before and } \\
\text { after the labor movement } \\
\text { the size of material incentives }\end{array}$ & $\begin{array}{l}\text { Characteristics of the individual as } \\
\text { a participant of labor movement: } \\
\text { level of education } \\
\text { age } \\
\text { state of health } \\
\text { professional experience } \\
\text { Characteristics of the workplace } \\
\text { before and after labor movement: } \\
\quad \text { working conditions } \\
\text { social protection of employees } \\
\text { vocational training } \\
\text { retraining, increase } \\
\text { qualifications } \\
\text { availability of social infrastructure } \\
\text { The level of intensity of labor } \\
\text { mobility }\end{array}$ \\
\hline
\end{tabular}

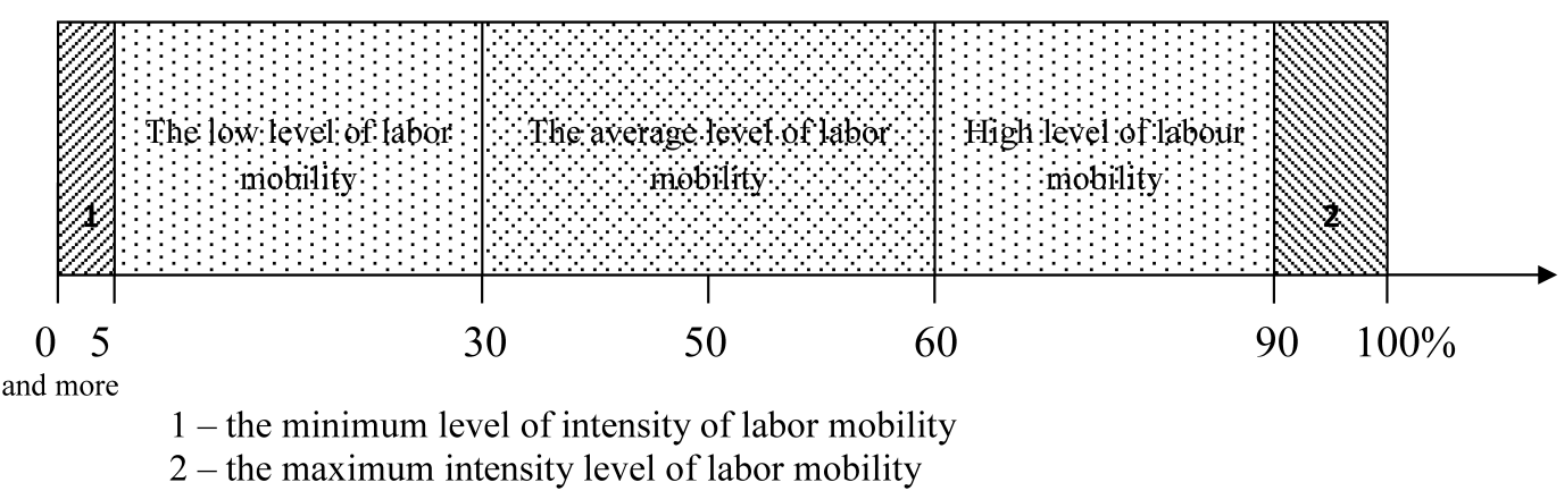

Fig. 2. Scale of assessment of the level of intensity of labor mobility

Flow "employed $\leftrightarrow$ unemployed":

$$
\mathrm{M}_{\text {ec.lm.e-u. }}=\left|\mathrm{E}_{1}-\mathrm{E}_{0}\right|+\left|\mathrm{U}_{1}-\mathrm{U}_{0}\right|
$$

where $\mathrm{M}_{\mathrm{ec} . \mathrm{Im}}$ - the magnitude of the economic labor mobility;

$\mathrm{E}_{0,1}-$ number of persons engaged in economic activity in the base and reporting periods, respectively; 
$\mathrm{U}_{0,1}$ - the number of unemployed as defined by the ILO in the base and reporting periods, respectively.

Flow "economically active population $\leftrightarrow$ economically inactive population":

$$
\mathrm{M}_{\text {ec.lm.eap-enp. }}=\left|\mathrm{EAP}_{1}-\mathrm{EAP}_{0}\right|+\left|\mathrm{ENP}_{1}-\mathrm{ENP}_{0}\right| \text {, }
$$

where $\mathrm{EAP}_{0,1}-$ number of economically active population in the base and reporting periods, respectively;

$\mathrm{ENP}_{0,1}$ - the number of economically inactive population in the base and reporting periods, respectively.

The flow of "employed $\leftrightarrow$ employed" is characterized by the change of the individual from one workplace to another. This flow is also represented by labor movements in the direction of the individual's transition from hired labor to entrepreneurial activity or in the opposite direction, that is, from entrepreneurial activity to employment:

$$
\mathrm{M}_{\text {ec.lm.e-e. }}=\mathrm{C}+\mathrm{M} \text {, }
$$

where $\mathrm{C}$ - the number of individuals who changed one workplace to another during the analyzed period;

$\mathrm{M}$ - the number of individuals who have moved from hired labor to entrepreneurial activities or Vice versa.

The intensity of labour mobility for the "employed $\leftrightarrow$ unemployed" flow is calculated as follows:

$$
L_{\text {ec.lm.e }-u}=\frac{\left|E_{1}-E_{0}\right|+\left|U_{1}-U_{0}\right|}{E A P_{1}} \cdot \mathbf{1 0 0},
$$

where $\mathrm{EAP}_{1}$ - number of economically active population during the reporting period.

For the flow "economically active population $\leftrightarrow$ economically inactive population" the intensity level is equal to:

$$
L_{\text {ec.lm.eap-enp }}=\frac{\left|E A P_{1}-E A P_{0}\right|+\left|E N P_{1}-E N P_{0}\right|}{E A P_{1}} \cdot 100,
$$

For flow « employed $\leftrightarrow$ employed ":

$$
L_{\text {ec.lm.e }-e}=\frac{C+M}{E A P_{1}} \cdot 100 .
$$

The results of calculations of the magnitude and intensity level of economic labor mobility flows are given in table 3 . 
Table 3

\section{Assessment of the economic flows of the labour mobility of young people}

\begin{tabular}{|l|c|c|c|}
\hline \multicolumn{1}{|c|}{ Flow direction } & $\begin{array}{l}\text { Period of labor } \\
\text { mobility,years }\end{array}$ & $\begin{array}{c}\text { The value of } \\
\text { labor mobility } \\
\text { (B), thousand } \\
\text { people }\end{array}$ & $\begin{array}{c}\text { Level of } \\
\text { intensity of } \\
\text { labor mobility } \\
\text { (P), \% }\end{array}$ \\
\hline $\begin{array}{l}\text { Employed } \leftrightarrow \text { unemployed } \\
\text { (population aged 15-34) }\end{array}$ & $2015-2016$ & 156,8 & 2,39 \\
\hline $\begin{array}{l}\text { Economically active } \\
\text { population } \leftrightarrow \text { economically } \\
\text { inactive population aged } \\
15-34\end{array}$ & $2015-2016$ & 203,6 & 3,1 \\
\hline Employed $\leftrightarrow$ employed & $\begin{array}{l}\text { Calculation of the value and intensity factor of } \\
\text { labor mobility behind the flow of "employed } \leftrightarrow \\
\text { employed" at this stage is impossible, because } \\
\text { there are no data reflecting the quantitative } \\
\text { characteristics of these movements }\end{array}$ \\
\hline
\end{tabular}

Thus, the intensity of economic labor mobility in accordance with the scale of labor mobility intensity is estimated as minimal, which indicates low labor mobility among the entire population and among young people.

For territorial labor mobility the value of labor movements is calculated depending on its types: interstate, interregional and intraregional.

Depending on the directions of labor movement flows, the value and intensity factor of territorial labor mobility are calculated.

The value of territorial labor mobility is defined as follows:

$$
\mathrm{V}_{\text {terr.lm. }}=\mathrm{N}_{\text {arr. }}+\mathrm{N}_{\text {dep. }} \text {, }
$$

where $\mathrm{V}_{\text {terr.lm. }}$ - the value of territorial labor mobility;

$\mathrm{N}_{\text {arr. }}, \mathrm{N}_{\text {dep. }}$ - the number of arrivals and departures of the region's population of working age, respectively.

Size of intergovernmental, interregional and intraregional territorial labor mobility ( $\mathrm{V}_{\text {terr.intergov.lm., }} \mathrm{V}_{\text {terr.interreg.lm. and }} \mathrm{V}_{\text {terr.intrareg.lm. }}$ ) depends on the number of arrivals and departures of the region's population at working age for each flow of labor movements, respectively. 
The level of intensity of territorial labor mobility $\left(\mathrm{L}_{\text {terr.lm. }}\right)$ is calculated by the formula:

$$
L_{\text {terr.lm. }}=\frac{V_{\text {terr.lm }}}{P_{1}} \cdot 100,
$$

where $\mathrm{P}_{1}-$ the population of the region at working age for the reporting period.

Level of intensity of intergovernmental, interregional and intraregional territorial labor mobility $\left(\mathrm{V}_{\text {terr.intergov.lm., }} \mathrm{V}_{\text {terr.interreg.lm. and }}\right.$ $\mathrm{V}_{\text {terr.intrareg.lm. }}$ ) is calculated as the ratio of the number of the arrived and departing population of the region at the working age for each flow of labor movements, respectively, to the number of economically active population, according to the ILO, of the region for the analyzed period.

The results of calculations of the magnitude and intensity level of territorial labor mobility flows are presented in table 4 .

Table 4

Assessment of territorial labour mobility flows of young people

\begin{tabular}{|l|c|c|c|}
\hline Flow direction & $\begin{array}{c}\text { Period of labor } \\
\text { mobility,years }\end{array}$ & $\begin{array}{c}\text { The value of } \\
\text { labor mobility } \\
\text { (B), thousand } \\
\text { people }\end{array}$ & $\begin{array}{c}\text { Level of } \\
\text { intensity of labor } \\
\text { mobility (P), \% }\end{array}$ \\
\hline $\begin{array}{l}\text { The overall } \\
\text { territorial labor } \\
\text { mobility in the age } \\
\text { of 15-35 years }\end{array}$ & $2015-2016$ & 12,9 & 0,11 \\
\hline
\end{tabular}

Thus, the quantitative assessment of territorial labor mobility, as well as economic, suggests that the registered territorial labor mobility is at a minimum level.

For internal industrial labor mobility, the value of labor movements is defined as the sum of accepted and dismissed workers for each type of economic activity for the analyzed period:

$$
\mathrm{V}_{\text {inter.ind.lm. }} \mathrm{N}_{\text {employed }}+\mathrm{N}_{\text {dismissed, }}
$$

where $\mathrm{V}_{\text {inter.sect.lm. }}$ - value of internally sectoral labor mobility;

$\mathrm{N}_{\text {employed }}, \mathrm{N}_{\text {dismissed }}$ - the number of employed and dismissed employees in the industry, respectively. 
The level of intensity internally sectoral labor mobility $\left(\mathrm{L}_{\text {inter.sect.1m. }}\right)$, calculated by the formula:

$$
L_{\text {inter.sect.lm. }}=\frac{N_{\text {employed }}+N_{\text {dismissed }}}{N_{1}} \cdot \mathbf{1 0 0},
$$

where $\mathrm{N}_{1}$ - the number of employees of the relevant industry for the analyzed period.

The calculation of the size and level of intensity of internally sectoral labour mobility among young people because of lacking of statistical data on the admission and dismissal of the population in the age group of 15-35 years by types of economic activity.

Youth labor mobility can be assessed by using indicators such as the magnitude and intensity of labor mobility, which will help to make a comparative analysis of the intensity of flows of all forms of labour mobility and to assess the extent of their labor movements.

Thus, labor mobility is one of the main factors that ensures the flexibility of the labor market. The high level of labor mobility means the fundamental readiness of the population to change the position, profession, place of work and residence, lifestyle in General. In fact, mobility is the key to the success of relevant programmes to combat unemployment.

The determination of the directions of youth labor mobility flows helps to ensure that the labor market conditions, where demand for labor will correspond to its supply; redistribution of the labor force in accordance with changes in the labor market, and consequently, production needs; increasing employment and reducing unemployment.

\section{SUMMARY}

It is established that an important component of the definition of labor mobility is the analysis of migration of economically active youth. The existing negative trends in the development of socio-economic processes, which have become sustainable and are reflected primarily in such phenomena as high unemployment; low price of labor, and as a consequence, low income of the bulk of the population; the imbalance between the supply and demand of labor and limited opportunities for effective employment.

Analysis of the structure of migration of the population of Ukraine indicates that during the study period there were changes in the intensity and direction of migration flows. The dynamics of population losses due to migration tends to decrease, although there are some fluctuations. It should 
be taken into account that the main share of participants in these processes falls on the working part of the population. It can be considered that an important problem of modern Ukrainian society should be considered the strengthening of migration sentiments, especially for young people.

\section{REFERENCES}

1. Unified tariff and qualification directory of works and professions of workers / State Committee of the Council of Ministers of the USSR on labor and wages. Moscow : Mechanical Engineering, 1969. Issue. 2. P. 549.

2. Tarnavsky M. P. Migration processes in Ukraine: causes and consequences. Scientific works of Kirovograd national technical University. Series: Economic Sciences. 2012. Issue. 22. Part 1. P. 4.

3. First all-Ukrainian population census: historical, methodological, social, economic, ethnic aspects / [N. S. Vlasenko E. M. Libanova, A. G. Osaulenko, etc.]; ed. I. F. Kuras, S. I. Pirozhkova. Kyiv : IVTs state statistics Committee of Ukraine, 2004. P. 340.

4. Demographic crisis in Ukraine: its causes and consequences / [ed. S. I. Pirozhkova]. Kyiv : IVTs. State statistics Committee of Ukraine, 2003. P. 42.

5. Statistical Bulletin "External labour migration (based on the results of a modular sample survey)" / [resp. for issue I. V. Senik]. Kyiv : State statistics service of Ukraine, 2017. 36 p.

6. First all-Ukrainian population census: historical, methodological, social, economic, ethnic aspects / [N. S. Vlasenko E. M. Libanova, A. G. Osaulenko, etc.]; ed. I. F. Kuras, S. I. Pirozhkova. Kyiv : IVTs state statistics Committee of Ukraine, 2004. P. 345.

7. Stadnyj Y. Number of Ukrainian students abroad. URL: http://www.cedos.org.ru/RU/osvita/56

8. Stadnyj Y There are Ukrainian students behind the cordon. URL: http://www.cedos.org.ua/uk/osvita/56

\section{Information about the author: Petrovskaya I. O.}

Candidate of Economic Sciences, Associate Professor, Department of Economic, Enterprise and Natural Management, V. I. Vernadsky Taurida National University 33, John McCain str., Kyiv, 02000, Ukraine 